DOI: $10.17957 / \mathrm{IJAB} / 15.1774$

http://www.fspublishers.org

\title{
Root Foraging in Soybean (Glycine max) under Nitrogen Deprivation
}

\author{
Muhammad Adnan Tabassum, Yi Dai ${ }^{1}$, Zhenzhi Pan', Lin Chen', Muhammad Saleem², Muhammad Aurangzaib ${ }^{3}$, \\ Guisheng Zhou' ${ }^{1}$ and Li Song ${ }^{{ }^{*}}$ \\ ${ }^{1}$ Joint International Research Laboratory of Agriculture and Agri-Product Safety, The Ministry of Education of China, \\ Institutes of Agricultural Science and Technology Development, Yangzhou University, Jiangsu, P. R. China \\ ${ }^{2}$ College of Bioscience and Biotechnology, Yangzhou University, Jiangsu, P. R. China \\ ${ }^{3}$ Dept. of Agronomy, Faculty of Agriculture and Environmental Sciences, The Islamia University of Bahawalpur, Pakistan \\ *Correspondence: songli@yzu.edu.cn \\ Received 24 October 2020; Accepted 20 February 2021; Published 16 April 2021
}

\begin{abstract}
Nitrate is one of the key sources of nitrogen in natural and agricultural soils. The distribution and concentration of nitrate determine root system architecture in plants. Soybean (Glycine max L) is one of the key leguminous crops, while farmers rarely apply nitrogen in soybean crops except for a starter nitrogen dose at the time of sowing. However, the effects of severe deficiency nitrate on early seedling establishment of soybean before nodulation are not yet studied. Therefore, this study evaluated the effects of high dose of nitrate $(54.3 \mathrm{~m} M)$ and its deprivationon $(0 \mathrm{~m} M)$ on the root system architecture of soybean during seedling establishment. Results showed that the root traits including primary root length, fresh biomass, total length, surface area, tips, forks, and its crossings were significantly higher under no nitrate condition than nigh nitrate condition except for root volume, its dry biomass and diameter. Shoot growth attributes such as shoot length, shoot fresh biomass, shoot dry biomass, single leaf area, soil-plant analysis development value, and photosynthesis was significantly decreased while leaf dry mass per area was increased significantly under no nitrate condition. Furthermore, high nitrate supply significantly enhanced the content of nitrate in root tissue, but there was no significant difference between low and optimal nitrate supply. In summary, this study indicated that soybean root system architecture adopts a foraging strategy under nitrogen deprived environment. (C) 2021 Friends Science Publishers
\end{abstract}

Keywords: Soybean; Nitrate; Root system architecture; Foraging

\section{Introduction}

Nitrogen $(\mathrm{N})$ is a primary mineral nutrient required in huge quantity for plants to support plant growth and development, but it is present in less quantity in natural and agricultural soils (Lark et al. 2004). There are various sources of $\mathrm{N}$ like nitrate $\left(\mathrm{NO}_{3}{ }^{-}\right)$, ammonium $\left(\mathrm{NH}_{4}{ }^{+}\right)$, organic amino acids and peptides that plants can absorb. Nitrate is the key form of $\mathrm{N}$ found in both natural and agricultural soils which may act as a signaling molecule that shapes the root system architecture (RSA) (Alboresi et al. 2005; Marín et al. 2011; Alvarez et al. 2012). The $\mathrm{NO}_{3}{ }^{-}$distribution and concentration are key players to determine the plant RSA (Gruber et al. 2013; Tian et al. 2014).

Roots are vital in plant production as roots anchor plants in soil/growth medium, provide mechanical support, ensure water and nutrient uptake, facilitate symbiosis development and serve as storage organs in plants. The root elongation, lateral root branching as well as root angles, and root longevity make the root system, while genetic, environmental, and physiological factors are the major determinants of the root system (Lynch and Brown 2012; Smith and Ive 2012). The RSA has developmental plasticity, which depends upon immediate soil environments such as soil water status, soil nutrients, soil temperature, soil $\mathrm{pH}$, and soil microbes. As soil resources are distributed unevenly, therefore, the RSA is crucial for agricultural productivity and is the primary determinant of plant's capacity for the acquisition of soil resources (Lynch 1995).

The plant's ability to efficiently and quickly acquire the nutrients from natural and agricultural soils determine the comparative success rate and production of plants. As mineral nutrients interact in different ways, with each other and with soil particles, or water may carry them out of the plant's root range, which cause nutrients availability decrease and lead to nutrient scarcity. Therefore, plants activate their root foraging system to obtain nutrients from nutrient-rich patches. Root foraging consists of morphological modifications like RSA modulation or formation of root hairs, as well as physiological changes like roots release exudates to mobilize nutrients or changes the expression of nutrient transporters (Gojon et al. 2009; 
Hinsinger et al. 2009; Gruber et al. 2013). This root foraging enhances the interaction between root and soil and improve the ability of plant to capture immobile nutrients. Plants symbiosis with microbes also modifies RSA to some extent (Gutjahr and Paszkowski 2013).

Soybean is a key oilseed crop with a rich source of protein. The global soybean yield is increasing continuously and significantly since last several decades (FAO 2012; Kokubun 2013). Almost all crops require a large amount of $\mathrm{N}$ in order to achieve higher production goals, especially the legumes due to their higher seed protein content (Sinclair and Wit 1976; Giller and Cadisch 1995). Soybean shoots accumulate on an average of $79 \mathrm{~kg} \mathrm{~N}^{-1}$ to gain additional $\mathrm{Mg}$ of seed with seed $\backslash$ standard moisture content of $0.130 \mathrm{~kg}$ $\mathrm{H}_{2} \mathrm{O}$ per $\mathrm{kg}$ seed (Salvagiotti et al. 2008; Tamagno et al. 2017). The soybean crop rarely recieves $\mathrm{N}$ fertilizer provided by farmers except for a starter dose of $\mathrm{N}$ that is applied at sowing time, to meet early seedling emergence/germination stage requirement until nodulation takes place. The investigation indicates whether soil $\mathrm{N}$ mineralization and $\mathrm{N}$ fixation can meet the $\mathrm{N}$ requirement for a seed yield of 6 to $8 \mathrm{Mg}$ per hectare under wellmanaged field conditions (Menza et al. 2017). However, the effect of nitrate deficiency on seedling growth in the early seedling stage before nodulation has not been reported. Therefore, the present study examined the (a) effects of high nitrate supply or its deprivation on seedling establishment and root system architecture, and (b) variations in root foraging in soybean in response to nitrate application.

\section{Materials and Methods}

\section{Seed selection, sterilization and sowing}

The experiment was conducted using soybean (Glycine max L) variety Williams 82. Healthy and uniform seeds were selected and sterilized using bleach containing 5\% sodium hypochlorite and hydrochloric acid in a ratio of 10:1(v/v). Briefly, the bleach was taken in a beaker and placed below the porous plate of a glass desiccator apparatus, while, seeds were placed in petri dishes in a single layer kept above the porous plate of the glass desiccator. To avoid evaporation from the glass desiccator apparatus, the lid was closed using wax and left it in a fume hood overnight. After sterilization, seeds were soaked in tap water for $3 \mathrm{~h}$, and the imbibed seeds were sown in trays for germination till 7 days.

\section{Experimental treatments}

The physiological experiment was comprised of two treatments viz., with and without $\mathrm{KNO}_{3}$, which started from the first day of sowing. The treatment with $\mathrm{KNO}_{3}$ was named as high nitrate $(54.3 \mathrm{~m} M)\left(\mathrm{N}_{1}\right)$ while without $\mathrm{KNO}_{3}$ was named as no nitrate $(0 \mathrm{mM})\left(\mathrm{N}_{0}\right)$. One more treatment was added for the nitrate content analysis experiment. This treatment was name as optimum nitrate $(18.81 \mathrm{~m} M)$. The
$\mathrm{KCl}$ was used to make up the concentration of $\mathrm{K}$ across three treatments. The nutrient medium was liquid MS with little modification that $\mathrm{NH}_{4} \mathrm{NO}_{3}$, sucrose, and agar were not used while the additional amount of $\mathrm{KCl}$ was used in $\mathrm{N}_{0}$ treatment, to compensate additional potassium added as $\mathrm{KNO}_{3}$ in high nitrate treatment. The $\mathrm{pH}$ of the solution was adjusted to 5.8 with $\mathrm{NaOH}$ solution. After 7 days, seedlings were transplanted into other trays having the same concentration of MS medium solution and replicated three times. The MS solution was changed every $5^{\text {th }}$ day.

\section{Growth environment}

The experiment was conducted in a growth chamber (RXZ500D, model number JN181018, Ningbo Jiangnan Instrument Co., Ltd., Ningbo, China), with day/night duration of $16 / 8 \mathrm{~h}$ with a relative humidity of $60 \%$ and day/night temperature of $25^{\circ} \mathrm{C}$. Data were collected after 4 weeks of sowing.

\section{Gas exchange attributes}

Photosynthesis and other gas exchange attributes were recorded inside the growth chamber using Portable Photosynthesis Instrument (LI-6400XT; LI-COR Inc., Lincoln, NE, U.S.A.). The light source was red-blue LED, having $1000 \mu \mathrm{mol} \mathrm{m} \mathrm{m}^{-2} \mathrm{~s}^{-1}$ light intensity and carbon dioxide concentration of $399 \pm 9.45 \mu \mathrm{mol} \mathrm{mol}{ }^{-1}$. The leaf temperature was kept at $25^{\circ} \mathrm{C}$. The first trifoliate leaf was used to record photosynthesis data and each reading was recorded at a steady state. The SPAD value was also measured with an SPAD meter before start to each photosynthesis measurement.

\section{Root and shoot growth attributes}

Root and shoot lengths were measured in centimeters $(\mathrm{cm})$. After measuring the primary root and shoot length, root and shoot fresh biomass were measured with a digital electric weighing balance (LS220A, Precisa, Shanghai, China). Tissue papers were used to absorb the water present on the root surface before recording the fresh biomass. The same roots were packed in plastic bags and kept in the refrigerator at $4^{\circ} \mathrm{C}$ to measure the other root parameters. The complete roots of each plant were scanned with a root scanner (Epson Expression 1680 Scanner, Seiko Epson Co., Japan), and total root length, root surface area, root diameter, root volume, root tips, forks, and crossings were determined through the Root Analyzer (Regent Instruments Inc., Quebec, Canada). Both shoot and root samples were packed in paper envelopes and kept in an oven at $80^{\circ} \mathrm{C}$ for 5 days until constant count, and their dry biomass was recorded with a digital electric weighing balance (LS220A, Precisa, Shanghai, China).

\section{Leaf attributes}

After measuring the fresh biomass of shoots, all leaves of 
each plant were separated and the leaf area was measured by LI-3100C leaf area meter (LI-COR Inc., Lincoln, NE, USA). Then leaf samples were oven-dried at $80^{\circ} \mathrm{C}$ for 5 days and leaf dry biomass was recorded with a digital electric weighing balance. The leaf biomass per area (LMA) was determined by dividing leaf dry mass with leaf area. The single leaf area was calculated by dividing the whole leaf area with the number of total leaves on each plant.

\section{Nitrate assay for soybean tissues}

The salicylic acid method was used to evaluate the nitrate content in soybean root, stem and leaf tissues (Zhao and Wang 2017). Briefly, $0.1 \mathrm{~g}$ of fresh soybean tissues was grinded into powder by liquid nitrogen using a Tissuelyser96 (Jingxin, Shanghai, China). A $1 \mathrm{~mL}$ of deionized water was added into the tubes and the mixture was placed in a water bath at $100{ }^{\circ} \mathrm{C}$ for $30 \mathrm{~min}$. The $0.1 \mathrm{~mL}$ supernatant and $0.4 \mathrm{~mL}$ salicylic acid-sulphuric acid was used for incubating the reaction. After adding $9.5 \mathrm{~mL}$ of $8 \%(\mathrm{w} / \mathrm{v})$ $\mathrm{NaOH}$ solution into each tube, the tubes were cool down to room temperature (20-30 $\mathrm{min})$, the OD410 value of each sample was measured with a visible light spectrophotometer (NanoReady FC-1100, Suizhen, Hangzhou, China) with the control (deionized water) for reference. The nitrate content were calculated using the following equation: nitrate concentration $(\mu \mathrm{g} / \mathrm{g})=$ (nitrate content in the standard curve $\times$ the total volume of extracted sample) / (test amount of sample solution $\times$ weight of the sample).

\section{Statistical analysis}

Statistical analysis was performed using Statistics 8.1 software and completely randomized design with three replicates to assess treatment differences.

\section{Results}

\section{Effect of nitrate treatments on the root and shoot traits}

The effect of nitrate treatment was significant on the primary root, shoot and plant length (Table 1). The primary root length was significantly increased while shoot length decreased under no nitrate condition compared to high nitrate treatment. In addition, plant length was also significantly decreased under high nitrate treatment. The primary root length showed a higher increase $(42.5 \%)$ than the total plant length $(14.8 \%)$ while the shoot length decreased by $17.2 \%$ under no nitrate condition compared to high nitrate treatment.

Root fresh biomass was higher while shoot and plant fresh biomass was lower under no nitrate condition compared to high nitrate treatment (Table 1). Compared with high nitrate treatment, root fresh mass was significantly increased by $20.0 \%$ while shoot and plant fresh biomasses decreased under no nitrate condition by 64.9 and $33.1 \%$, respectively.
The effect of nitrate supply on shoot dry biomass was significant. As shown in Table 1, the shoot dry biomass was significantly decreased by $21.4 \%$ under no nitrate condition compared to high nitrate treatment. Although, there was no significant difference in root and plant dry biomass between nitrate treatments, root dry biomass increased $8.2 \%$ and plant dry biomass decreased $16.0 \%$ under no nitrate condition compared to high nitrate treatment.

\section{Effect of nitrate treatment on gas exchange attributes}

The single leaf area was significantly reduced by $25.8 \%$ in no nitrate treatment against high nitrate condition (Table 2). Leaf dry mass per area was higher in control without nitrate supply than high nitrate treatment which increased by $29.8 \%$. The SPAD value of no nitrate treatment was significantly lower than high nitrate treatment by $25.8 \%$.

Photosynthesis (A) significantly increased by $130.7 \%$ in high nitrate treatment compared with no nitrate condition. The inhibition rate of stomatal conductance $\left(\mathrm{g}_{\mathrm{s}}\right)$ was the highest (154.9\%) amongst in photosynthetic traits. Compared with high nitrate treatment, $g_{s}$ decreased significantly under no nitrate treatment. No significant treatment effect was found for intercellular $\mathrm{CO}_{2}$ concentration $\left(\mathrm{C}_{\mathrm{i}}\right)$. However, a significant treatment effect was observed in the transpiration rate $(\mathrm{Tr})$, and the $\mathrm{Tr}$ of high nitrate treatment recorded $117.3 \%$ higher than no nitrate treatment.

\section{The effect of nitrate treatment on root system architecture}

The effect of nitrate treatment on root related parameters was significant. The total root length was $25.7 \%$ higher under no nitrate condition than high nitrate supply condition (Table 3). Root surface area was increased by $16.9 \%$ under no nitrate treatment compared with high nitrate treatment. Contrary to total root length and root surface area, root diameter of no nitrate treatment was significantly lower than high nitrate treatment. The root volume of high nitrate treatment was increased by $7.5 \%$ compared with no nitrate treatment; but the effect was not statistically significant. Root tips, forks, and crossings also showed significant variations in response to nitrate treatment. Under no nitrate treatment, root crossings had the highest increment (32.9\%), followed by root tips $(30.6 \%)$ and root forks $(23.6 \%)$.

\section{The nitrate uptake under different nitrate concentration}

To reveal the nitrate uptake in soybean, we evaluate the nitrate content in roots, stem and leaf under low $(6.27 \mathrm{mM})$, optimum (18.81 $\mathrm{m} M)$, and high $(54.3 \mathrm{~m} M)$ nitrate treatments. The nitrate content in root tissue increased with the increase of nitrate concentration in solution. The higher nitrate content was found under high nitrate treatment. No significant difference was found between low and optimal 
Root Foraging in Soybean under Nitrogen Deprivation / Intl J Agric Biol, Vol 25, No 5, 2021

Table 1: Effect of nitrate supply on shoot and root growth attributes of soybean variety Wm 82

\begin{tabular}{|c|c|c|c|c|}
\hline Traits Name (Units) & ANOVA & & ts (Means \pm SE) & Difference (\%) \\
\hline Growth related & & $\mathrm{N}_{0}\left(\mathrm{KNO}_{3}=0 \mathrm{~m} M\right)$ & $\mathrm{N}_{1}\left(\mathrm{KNO}_{3}=54.3 \mathrm{~m} M\right)$ & \\
\hline Primary root length $(\mathrm{cm})$ & $* * *$ & $34.15 \pm 0.97 \mathrm{a}$ & $19.63 \pm 0.57 b$ & -42.5 \\
\hline Shoot length $(\mathrm{cm})$ & *** & $29.49 \pm 0.68 b$ & $34.56 \pm 0.65 a$ & 17.2 \\
\hline Plant length $(\mathrm{cm})$ & $* * *$ & $63.64 \pm 1.07 \mathrm{a}$ & $54.19 \pm 0.94 b$ & -14.8 \\
\hline Root fresh biomass (g) & $* * *$ & $1.69 \pm 0.12 \mathrm{a}$ & $1.35 \pm 0.14 \mathrm{~b}$ & -20.0 \\
\hline Shoot fresh biomass (g) & $* * *$ & $2.82 \pm 0.18 b$ & $4.65 \pm 0.36 \mathrm{a}$ & 64.9 \\
\hline Plant fresh biomass (g) & $* * *$ & $4.51 \pm 0.26 b$ & $6.00 \pm 0.49 \mathrm{a}$ & 33.1 \\
\hline Root dry biomass (g) & $\mathrm{ns}$ & $0.09 \pm 0.006 \mathrm{a}$ & $0.08 \pm 0.009 \mathrm{a}$ & -8.2 \\
\hline Shoot dry biomass (g) & $*$ & $0.41 \pm 0.03 b$ & $0.50 \pm 0.05 a$ & 21.4 \\
\hline $\begin{array}{l}\text { Plant dry biomass } \\
\left(\mathrm{g} \text { seedling }^{-1}\right)\end{array}$ & $\mathrm{ns}$ & $0.50 \pm 0.031 \mathrm{a}$ & $0.58 \pm 0.054 \mathrm{a}$ & 16.0 \\
\hline
\end{tabular}

Table 2: Effect of nitrate supply on leaf and photosynthesis-related attributes of soybean variety Wm 82

\begin{tabular}{|c|c|c|c|c|}
\hline Photosynthesis-related & ANOVA & & ts (Means \pm SE) & Difference $(\%)$ \\
\hline Traits Name (Units) & & $\mathrm{N}_{0}\left(\mathrm{KNO}_{3}=0 \mathrm{~m} M\right)$ & $\mathrm{N}_{1}\left(\mathrm{KNO}_{3}=54.3 \mathrm{~m} M\right)$ & \\
\hline Single leaf area $\left(\mathrm{cm}^{2}\right)$ & $* *$ & $20.70 \pm 1.70 b$ & $26.04 \pm 1.90 \mathrm{a}$ & 25.8 \\
\hline Leaf dry biomass/area $\left(\mathrm{gcm}^{-2}\right)$ & $* * *$ & $21.46 \pm 0.018 \mathrm{a}$ & $15.07 \pm 0.013 b$ & -29.8 \\
\hline Soil plant analysis development & $* * *$ & $18.30 \pm 0.61 b$ & $23.02 \pm 0.52 \mathrm{a}$ & 25.8 \\
\hline $\begin{array}{l}\text { Photosynthesis } \\
\left(\mu \mathrm{mol} \mathrm{m}{ }^{-2} \mathrm{~s}^{-1}\right)\end{array}$ & $* * *$ & $5.11 \pm 0.25 b$ & $11.78 \pm 0.28 \mathrm{a}$ & 130.7 \\
\hline $\begin{array}{l}\text { Stomatal conductance } \\
\left(\mathrm{mol} \mathrm{m}^{-2} \mathrm{~s}^{-1}\right)\end{array}$ & $* * *$ & $0.08 \pm 0.008 b$ & $0.20 \pm 0.012 \mathrm{a}$ & 154.9 \\
\hline 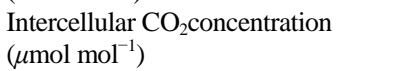 & ns & $271 \pm 6.12 \mathrm{a}$ & $271 \pm 6.66 \mathrm{a}$ & 0.2 \\
\hline Leaf transpiration rate $\left(\mathrm{mmol} \mathrm{m}^{-2} \mathrm{~s}^{-1}\right)$ & $* * *$ & $1.15 \pm 0.11 \mathrm{~b}$ & $2.49 \pm 0.12 \mathrm{a}$ & 117.3 \\
\hline
\end{tabular}

nitrate content. In addition, there was no significant difference on the effects of the three treatments on soybean stem and leaf tissues, although optimal nitrate treatment had highest nitrate content both in leaf and stem tissues of soybean (Table 4).

\section{Discussion}

Under optimal growth conditions, plants usually have a lower root to shoot ratio as these distribute more photosynthates to above-ground plant parts, resulting in the accumulation of above-ground biomass. Nevertheless, plant growing under $\mathrm{N}$ deficit conditions always have a higher root to shoot ratio, which indicates that above-ground plant parts were more affected by $\mathrm{N}$ deficiency than the underground roots (Ruggiero and Angelino 2007; Zhang et al. 2009; Lima et al. 2010; Ju and Christie 2011). Similarly, researchers reported that moderate $\mathrm{N}$ fertilization favored root growth of winter wheat while higher $\mathrm{N}$ supply resulted in reduced root growth in subsoil (Svoboda 2006). Low N availability increased root dry biomass (Wang et al. 2009). Similar results were observed in present study as primary root length, root fresh biomass, and root dry biomass were increased while shoot length, shoot fresh mass, root dry mass (Table 1) and leaf expansion (Table 2) were decreased under no nitrate treatment due to reduction in photosynthesis.
The roots with longer root length and greater surface areas have resistance to nutrient diffusion, and explore higher soil volume to uptake $\mathrm{N}$ under low $\mathrm{NO}_{3}{ }^{-}$ concentrations (Engels and Marschner 1995; Lawlor 2002). In present study, higher primary root length, total root length, root surface area, root volume, number of root tips, forks and crossings (Table 3) were observed under no nitrate treatment than high nitrate treatment. Because $\mathrm{NO}_{3}{ }^{-}$acts as an essential nutrient that limits growth and a key signaling molecule for gene expression, plant metabolism, plant growth and development, leaf expansion, root architecture, flowering time, and seed dormancy (Scheible et al. 2004; Zhang et al. 2007; Vidal and Gutiérrez 2008; Gojon et al. 2009; Krouk et al. 2010). Therefore, both primary root length and lateral root length increased (Table 1 and 3 ) under no nitrate environment that is consistent with previous results since $\mathrm{NO}_{3}{ }^{-}$deficient environment promotes primary root elongation and stimulates lateral root growth by regulating auxin activity (Vidal et al. 2010).

The NRT1.1 or CHL1 is a dual affinity transporter, while NRT 2.1 is a high-affinity transporter under low $\mathrm{NO}_{3}{ }^{-}$ availability. It has been reported in Arabidopsis that both are involved in nitrate acquisition from the soil solution. In addition, mutation studies have shown that these transporters are either indirectly or directly involved in $\mathrm{NO}_{3}{ }^{-}$ 
Tabassum et al. / Intl J Agric Biol, Vol 25, No 5, 2021

Table 3: Effect of nitrate supply on root architecture of soybean variety Wm 82

\begin{tabular}{|c|c|c|c|c|}
\hline Traits Name (Units) & ANOVA & & ts (Means \pm SE) & Difference (\%) \\
\hline Root related & & $\mathrm{N}_{0}\left(\mathrm{KNO}_{3}=0 \mathrm{~m} M\right)$ & $\mathrm{N}_{1}\left(\mathrm{KNO}_{3}=54.3 \mathrm{~m} M\right)$ & \\
\hline Total root length $(\mathrm{cm})$ & $* * *$ & $1156 \pm 79 a$ & $859 \pm 66 b$ & -25.7 \\
\hline Root surface area $\left(\mathrm{cm}^{2}\right)$ & ** & $145 \pm 10.58 \mathrm{a}$ & $120 \pm 10.35 b$ & -16.9 \\
\hline Root diameter (mm) & $*$ & $0.40 \pm 0.007 b$ & $0.48 \pm 0.037 \mathrm{a}$ & 19.1 \\
\hline Root volume $\left(\mathrm{cm}^{3}\right)$ & $\mathrm{ns}$ & $1.45 \pm 0.12 \mathrm{a}$ & $1.35 \pm 0.13 a$ & -7.0 \\
\hline Root tips (no) & $* * *$ & $1146 \pm 94 a$ & $796 \pm 59 b$ & -30.6 \\
\hline Root forks (no) & ** & $3105 \pm 288 \mathrm{a}$ & $2371 \pm 290 b$ & -23.6 \\
\hline Root crossings (no) & $* * *$ & $686 \pm 76 a$ & $460 \pm 50 \mathrm{~b}$ & -32.9 \\
\hline
\end{tabular}

Table 4: Effect of nitrate supply on nitrate uptake of soybean variety Wm 82

\begin{tabular}{|c|c|c|c|}
\hline Nitrate Concentration & Root $(\mu \mathrm{g} / \mathrm{g})$ & Stem $(\mu \mathrm{g} / \mathrm{g})$ & Leaf $(\mu \mathrm{g} / \mathrm{g})$ \\
\hline Low nitrate $(6.27 \mathrm{~m} M)$ & $52.35 \pm 5.10 \mathrm{~b}$ & $91.20 \pm 15.87 \mathrm{a}$ & $70.07 \pm 3.78 \mathrm{a}$ \\
\hline Suitable nitrate $(18.81 \mathrm{~m} M)$ & $68.80 \pm 14.94 b$ & $102.02 \pm 12.50 \mathrm{a}$ & $78.89 \pm 11.76 \mathrm{a}$ \\
\hline High nitrate $(54.3 \mathrm{~m} M)$ & $107.62 \pm 20.43 a$ & $85.40 \pm 16.85 \mathrm{a}$ & $64.47 \pm 15.93 a$ \\
\hline
\end{tabular}

signaling (Muños et al. 2004; Little et al. 2005; Remans et al. 2006; Ho et al. 2009; Wang et al. 2009, 2020). It was speculated that these transporters might also be present as a signaling molecule to promote root growth and reduce shoot growth in soybean under no or low nitrate condition (Table 1 and 2). However, the low affinity transporters family are active under high availability of nitrate (Krapp et al. 2011; Kotur et al. 2012; Gu et al. 2013, 2014; Léran et al. 2014; Liu et al. 2014). For example, high nitrate treatment promotes shoot growth and reduces root growth in the present study (Table 1 and 2).

Plant roots could sense nutrient concentration in the soil environment, increase nutrient uptake or its assimilation systems, as well as proliferate in nutrient-rich areas. This phenomenon is known as local signaling. On the other hand, when plant internal nutrient availability becomes inadequate, this phenomenon boosted the whole plant system, which is called systemic signaling (Schachtman and Shin 2007). This dual system regulation controls nutrients, such as $\mathrm{NO}_{3}^{-}$, which is one of the most growth-limiting nutrients. The current model of dual regulation indicates that root growth or development and $\mathrm{NO}_{3}^{-}$transport are regulated by (i) $\mathrm{NO}_{3}^{-}$itself locally and (ii) by reduced $\mathrm{N}$ metabolites through systemic feedback repression (Zhang $e t$ al. 1999; Gojon et al. 2009). The experimental results are in accordance where plants under the absence of local $\mathrm{N}\left(\mathrm{N}_{0}\right)$ increased root foraging by increasing root related parameters while under higher dose/presence of local $\mathrm{N}\left(\mathrm{N}_{1}\right)$ reduced root growth and development (Tables 1 and 3). In addition, the reduction of photosynthesis metabolism due to less photosynthetic enzymes/components and activities revealed the feedback suppression of the system under no nitrate condition.

When plant roots face $\mathrm{N}$ deficiency, the root system architecture behaves in two ways based on the degree of $\mathrm{N}$ deficiency (Giehl et al. 2012). The survival strategy in a severe $\mathrm{N}$ deficiency environment constitutes elongation of primary and lateral roots as well as inhibition of new lateral roots (Giehl et al. 2012; Giehl and Wirén 2014). This kind of adaptation depends upon a regulatory module along with the NRT1.1 dependent auxin removal from primordia of lateral roots (Araya et al. 2014, 2016). The relatively mild N deficiency rather than severe $\mathrm{N}$ limitation stimulates the lateral root emergence as well as primary and lateral root elongation particularly (Gruber et al. 2013; Giehl and Wirén 2014; Ma et al. 2014). This stimulatory response is an interesting strategy, in which roots enhance soil foraging volume is known as the foraging strategy. The upregulation of the auxin biosynthesis gene TAR2 was observed under low $\mathrm{N}$ conditions. Under mild $\mathrm{N}$ deficiency environment, tar2 mutant showed inhibition in lateral root emergence, thus auxin is considered to be an active role player (Ma et al. 2014). However, as primary and lateral root length of tar2 mutant was not affected, so TAR2-dependent auxin biosynthesis alone fails to explain the root elongation stimulation mechanism under mild $\mathrm{N}$ deficiency. In present study, soyeban root foraging strategy was found under severe nitrate deficiency as primary root length, total root length, and all other root related parameters showed increment except root diameter (Table 1 and 3). Further studies are needed to investigate the genetic behavior of root and shoot growth under excessive and deficient nitrate environments in soybean.

\section{Conclusion}

The $\mathrm{NO}_{3}{ }^{-}$deprivation or high dose/presence is a signal to monitor plant growth in soybean in the early growth stage before nodulation. The deprivation of $\mathrm{NO}_{3}{ }^{-}$promoted root growth in search of $\mathrm{NO}_{3}{ }^{-}$and showed a decrease in aboveground plant parts through local and systemic signaling. Similarly, the high dose/presence of $\mathrm{NO}_{3}{ }^{-}$promoted shoot 
growth and showed a decrease in root growth through local and systemic signaling. High nitrate supply significantly enhanced the nitrate contents in root tissue, but there was no significant difference between low and optimal nitrate supply. In summary, soybean roots act as plant foraging organs under $\mathrm{NO}_{3}{ }^{-}$absence environment.

\section{Acknowledgement}

This study was supported by Project of Special Funding for Crop Science Discipline Development of Yangzhou University (yzuxk202006).

\section{Author Contributions}

MT and LS designed experiment and wrote manuscript. YD, $\mathrm{ZP}$, LC, MS helped in performing experiments and analyzing data. MA and GZ helped in revising manuscript.

\section{Conflict of Interest}

We declare that the authors have no competing interests as defined by Nature Research, or other interests that might be perceived to influence the results and/or discussion reported in this paper.

\section{Data Availability}

All data will be available upon reasonable request to the corresponding author.

\section{Ethics Approval}

Not applicable.

\section{References}

Alboresi A, C Gestin, MT Leydecker, M Bedu, C Meyer, HN Truong (2005). Nitrate, a signal relieving seed dormancy in Arabidopsis. Plant Cell Environ 28:500-512

Alvarez JM, EA Vidal, RA Gutiérrez (2012). Integration of local and systemic signaling pathways for plant $\mathrm{N}$ responses. Curr Opin Plant Biol 15:185-191

Araya T, NV Wirén, H Takahashi (2016). CLE peptide signaling and nitrogen interactions in plant root development. Plant Mol Biol 91:607-615

Araya T, M Miyamoto, J Wibowo, A Suzuki, S Kojima, YN Tsuchiya, S Sawa, H Fukuda, N von Wirén, H Takahashi (2014). CLECLAVATA1 peptide-receptor signaling module regulates the expansion of plant root systems in a nitrogen-dependent manner. Proc Natl Acad Sci 111:2029-2034

Engels C, H Marschner (1995). Plant uptake and utilization of nitrogen. In: Nitrogen Fertilization in the Environment, pp:41-81. Bacan PE (Ed.). Marcel Dekker, Inc., New York, USA

FAO STAT (2012). Soybean production Indices. Available at: http://www.fao.org/faostat/en/\#data/QI

Giehl RF, NV Wirén (2014). Root nutrient foraging. Plant Physio 166:509-517

Giehl RF, JE Lima, NV Wirén (2012). Localized iron supply triggers lateral root elongation in Arabidopsis by altering the AUX1-mediated auxin distribution. Plant Cell 24:33-49
Giller KE, G Cadisch (1995). Future benefits from biological nitrogen fixation: An ecological approach to agriculture. In: Management of Biological Nitrogen Fixation for the Development of more Productive and Sustainable Agricultural Systems, pp:255-277. Ladha JK, MB Peoples (eds.). Developments in Plant and Soil Sciences, Springer, Dordrecht, The Netherlands

Gojon A, PNacry, JCDavidian (2009). Root uptake regulation: A central process for NPS homeostasis in plants. Curr Opin Plant Biol 12:328-338

Gruber BD, RF Giehl, S Friedel, NV Wirén (2013). Plasticity of the Arabidopsis root system under nutrient deficiencies. Plant Physiol 163:161-179

Gu C, X Zhang, J Jiang, Z Guan, S Zhao, W Fang, Y Liao, S Chen, F Chen (2014). Chrysanthemum CmNAR2 interacts with CmNRT2 in the control of nitrate uptake. Sci Rep 4; Article 5833

Gu R, F Duan, X An, F Zhang, NV Wirén, L Yuan (2013). Characterization of AMT-mediated high-affinity ammonium uptake in roots of maize (Zea mays L.). Plant Cell Physiol 54:1515-1524

Gutjahr C, U Paszkowski (2013). Multiple control levels of root system remodeling in arbuscular mycorrhizal symbiosis. Front Plant Sci 4; Article 204

Hinsinger P, AG Bengough, D Vetterlein, IM Young (2009). Rhizosphere: Biophysics, biogeochemistry and ecological relevance. Plant Soil 321:117-152

Ho CH, SH Lin, HC Hu, YF Tsay (2009). CHL1 functions as a nitrate sensor in plants. Cell 138:1184-1194

Ju X, P Christie (2011). Calculation of theoretical nitrogen rate for simple nitrogen recommendations in intensive cropping systems: A case study on the North China Plain. Field Crops Res 124:450-458

Kokubun M (2013). Genetic and cultural improvement of soybean for waterlogged conditions in Asia. Field Crops Res 152:3-7

Kotur Z, N Mackenzie, S Ramesh, SD Tyerman, BN Kaiser, AD Glass (2012). Nitrate transport capacity of the Arabidopsis thaliana NRT2 family members and their interactions with AtNAR2. 1. New Phytol 194:724-731

Krapp A, R Berthomé, M Orsel, S Mercey-Boutet, A Yu, L Castaings, S Elftieh, H Major, JP Renou, F Daniel-Vedele (2011). Arabidopsis roots and shoots show distinct temporal adaptation patterns toward nitrogen starvation. Plant Physiol 157:1255-1282

Krouk G, NM Crawford, GM Coruzzi, YF Tsay (2010). Nitrate signaling: Adaptation to fluctuating environments. Curr Opin Plant Biol 13:265-272

Lark RM, AE Milne, TM Addiscott, KWT Goulding, CP Webster, S O'Flaherty (2004). Scale-and location-dependent correlation of nitrous oxide emissions with soil properties: An analysis using wavelets. Eur J Soil Sci 55:611-627

Lawlor DW (2002). Carbon and nitrogen assimilation in relation to yield: Mechanisms are the key to understanding production systems. $J$ Exp Bot 53:773-787

Léran S, K Varala, JC Boyer, M Chiurazzi, N Crawford, F Daniel-Vedele, L David, R Dickstein, E Fernandez, B Forde, W Gassmann, D Geiger, A Gojon, JM Gong, BA Halkier, JM Harris, R Hedrich, AM Limami, D Rentsch, M Seo, YF Tsay, M Zhang, G Coruzzi, BA Lacombe (2014). A unified nomenclature of NITRATE TRANSPORTER 1/PEPTIDE TRANSPORTER family members in plants. Trends Plant Sci 19:5-9

Lima JE, S Kojima, H Takahashi, NV Wirén (2010). Ammonium triggers lateral root branching in Arabidopsis in an Ammonium transporter 1, 3-dependent manner. Plant Cell 22:3621-3633

Little DY, H Rao, S Oliva, F Daniel-Vedele, A Krapp, JE Malamy (2005). The putative high-affinity nitrate transporter NRT2.1 represses lateral root initiation in response to nutritional cues. Proc Natl Acad Sci 102:13693-13698

Liu X, D Huang, J Tao, AJ Miller, X Fan, G Xu (2014). Identification and functional assay of the interaction motifs in the partner protein $\mathrm{O}$ NAR 2.1 of the two-component system for high-affinity nitrate transport. New Phytol 204:74-80

Lynch J (1995). Root architecture and plant productivity. Plant Physio 109:7-13

Lynch JP, KM Brown (2012). New roots for agriculture: Exploiting the root phenome. Phil Trans Roy Soc B Biol Sci 367:1598-1604 
Ma W, J Li, B Qu, X He, X Zhao, B Li, X Fu, Y Tong (2014). Auxin biosynthetic gene TAR 2 is involved in low nitrogen-mediated reprogramming of root architecture in Arabidopsis. Plant J 78:70-79

Marín IC, I Loef, L Bartetzko, I Searle, G Coupland, M Stitt, D Osuna (2011). Nitrate regulates floral induction in Arabidopsis, acting independently of light, gibberellin and autonomous pathways. Planta 233:539-552

Menza NCL, JP Monzon, JE Specht, G Patricio (2017). Is soybean yield limited by nitrogen supply? Field Crops Res 213:204-212

Muños S, C Cazettes, C Fizames, F Gaymard, P Tillard, M Lepetit, L Lejay, A Gojon (2004). Transcript profiling in the chl1-5 mutant of Arabidopsis reveals a role of the nitrate transporter NRT1.1 in the regulation of another nitrate transporter, NRT2.1. Plant Cell 16:2433-2447

Remans T, P Nacry, M Pervent, S Filleur, E Diatloff, E Mounier, P Tillard, BG Forde, A Gojon (2006). The Arabidopsis NRT1.1 transporter participates in the signaling pathway triggering root colonization of nitrate-rich patches. Proc Natl Acad Sci 103:19206-19211

Ruggiero C, G Angelino (2007). Changes of root hydraulic conductivity and root/shoot ratio of durum wheat and barley in relation to nitrogen availability and mercury exposure. Ital J Agron 3:281-290

Salvagiotti F, KG Cassman, JE Specht, DT Walters, A Weiss, A Dobermann (2008). Nitrogen uptake, fixation and response to fertilizer $\mathrm{N}$ in soybeans: A review. Field Crops Res 108:1-13

Schachtman DP, R Shin (2007). Nutrient sensing and signaling: NPKS. Annu Rev Plant Biol 58:47-69

Scheible WR, R Morcuende, T Czechowski, C Fritz, D Osuna, N PalaciosRojas, D Schindelasch, O Thimm, MK Udvardi, M Stitt (2004). Genome-wide reprogramming of primary and secondary metabolism, protein synthesis, cellular growth processes, and the regulatory infrastructure of Arabidopsis in response to nitrogen. Plant Physiol 136:2483-2499

Sinclair TR, CTD Wit (1976). Analysis of the carbon and nitrogen limitations to soybean yield. Agron J 68:319-324
Smith S, DS Ive (2012). Root system architecture: Insights from Arabidopsis and cereal crops. Phil Trans Roy Soc B Biol Sci 367:1441-1452

Svoboda PH (2006). The effect of nitrogen fertilization on root distribution of winter wheat. Plant Soil Environ 52:308

Tamagno S, GR Balboa, Y Assefa, P Kovács, SN Casteel, F Salvagiotti, FO García, WM Stewart, IA Ciampitti (2017). Nutrient partitioning and stoichiometry in soybean: A synthesis-analysis. Field Crops Res 200:18-27

Tian H, ID Smet, Z Ding (2014). Shaping a root system: Regulating lateral versus primary root growth. Trends Plant Sci 19:426-431

Vidal EA, RA Gutiérrez (2008). A systems view of nitrogen nutrient and metabolite responses in Arabidopsis. Curr Opin Plant Biol 11:521-529

Vidal EA, V Araus, C Lu, G Parry, PJ Green, GM Coruzzi, RA Gutiérrez (2010). Nitrate-responsive miR393/AFB3 regulatory module controls root system architecture in Arabidopsis thaliana. Proc Natl Acad Sci 107:4477-4482

Wang B, L Tao, QW Huang, Y Xing-Ming, S Qi-Rong (2009). Effect of N fertilizers on root growth and endogenous hormones in strawberry. Pedosphere 19:86-95

Wang W, H Bin, AF Li, CC Chu (2020). NRT1.1s in plants: Functions beyond nitrate transport. J Exp Bot 71:4373-4379

Zhang H, H Rong, D Pilbeam (2007). Signalling mechanisms underlying the morphological responses of the root system to nitrogen in Arabidopsis thaliana. J Exp Bot 58:2329-2338

Zhang H, A Jennings, PW Barlow, BG Forde (1999). Dual pathways for regulation of root branching by nitrate. Proc Natl Acad Sci 96:6529-6534

Zhang X, S Chen, H Sun, Y Wang, L Shao (2009). Root size, distribution and soil water depletion as affected by cultivars and environmental factors. Field Crops Res 114:75-83

Zhao L, Y Wang (2017). Nitrate assay for plant tissues. Biochem Biophys Res Commun 43:1274-1279 